in the first place. Miles Cloyd of the University of Texas Medical Branch in Galveston, explains that "Virus particles readily invade host cells and copy their RNA into DNA but then there seems to be some post entry block that results in a nonproductive infection." Richard
Kaslow, of the University of Alabama at Birmingham, presented findings on a third mechanism involving the host's HLA "profile" that determines how rapidly the host progresses to disease. But these mechanisms cannot be the whole story. "These three different ge- netic elements together explain resistance in probably fewer than half of the people who remain uninfected, despite multiple exposures to HIV," says Cloyd. That implies that additional mechanisms are waiting to be discovered.

ORLA SMITH

With human organs in short supply and xenotransplantation facing serious safety concerns, countries around the world are struggling to find solutions. Nature Medicine presents reports from Japan, Brazil and the United States.

\section{Japan forges ahead on artificial organs}

Japan looks set to lead the search for a radical alternative to organ transplants. regeneration of human organs is expected to open in 1998. The center, tentatively named the Regenerative Medicine Institute, will aim to replace transplants in the next century with artificial organs and treatments based on tissue engineering and cell regeneration. It will be based at Kyoto University, one of Japan's most prestigious academic institutions.

Organ transplantation is particularly unpopular in Japan (Nature Medicine 2, $835 ; 1996)$. Many people are reluctant to accept the concept of "brain death," so that surgeons do not harvest livers and hearts from cadavers. Although transplants of complete livers and hearts are not technically illegal, currently no hospitals perform them. Whereas some researchers hope transplants might be introduced in Japan in the near future, they believe it is essential to explore new Its first research center dedicated to the

techniques. Under the plan, the new center will combine two university institutes, the Chest Disease Research Institute and the Research Center for Biomedical Engineering. One line of research that scientists are hoping to pursue is the removal and culture of cells from a diseased organ for later reintroduction into the original organ. The aim is to use the cultured cells to regenerate specific functions of the organ that have been lost through disease. For example, in the case of diabetes, researchers would extract cells from the pancreas and cultivate cells designed to secrete insulin. These cells would then be returned to restore normal function.

The center will have more than 35 fulltime researchers and should open next year after receiving final permission from the Ministry of Education, Science, Sports and Culture in December this year, according to Shigeki Hitomi, director of the university's Chest Disease Research Institute. RICHARD NATHAN Tokyo

\section{Brazil presumes donors' consent}

Brazil has passed a controversial law allowing surgeons to presume that all individuals consent to the use of their organs after their death unless their family objects. President Fernando Henrique Cardoso signed the policy onto the statute book on 4 February 1997 after a long debate in the legislature.

All countries face a widening gap between the supply and demand for transplant organs such as kidneys and livers. In the United States, for example, about 4,800 people each year donate organs after their death, but the waiting list for organs now numbers about 48,000 peo- ple, according to the Food and Drug Administration. In Latin America, widespread fears about organ stealing have discouraged some donors, further reducing supply. Eduardo Rocha, a nephrologist at the Federal Fluminense University in Rio de Janeiro, welcomes the new legislation because he hopes that it will dispel misconceptions about transplant science. But he recognizes that it may not be readily accepted with people. "There is some doubt as to whether Brazil is ready for informed consent," he says.

BARBARA NASTO New York
USA defends xenotransplant policy

The Food and Drug Administration has defended itself against criticisms of the US government's current policy for the experimental transplantation of animal organs. Last month, Jon Allan, a virologist at the Southwest Foundation for Biomedical Research in San Antonio, Texas, called the draft guidelines that permit xenotransplantation in the United States "vague." The guidelines, published last September, have also been attacked for lacking a formal, central oversight policy that would be similar to that announced by the Xenotransplant Interim Regulatory Authority that is being appointed in the UK (Nature Medicine 3,132 and 275; 1997).

Phil Noguchi, Director of the Cellular and Gene Therapies Division of the Food and Drug Administration, defends the position of the United States. "The guidelines are broad stroke on purpose to get the virologists and other concerned communities engaged in the process," he says. And he argues that there is a central oversight policy in the United States already, because anyone who wants to take xenotransplant technologies into the clinic must file an investigatory new drug application.

Officials at the Public Health Service in Washington, DC; the National Institutes of Health in Bethesda, Maryland; and the Centers for Disease Control in Atlanta, Georgia; are reviewing and preparing comments on the public's response to the xenotransplant guidelines.

BARBARA NASTO New York 